\title{
Comparative Study of the Core Basis of the Undergraduate Course of Musicology and the Course of "Peking Education Plan"
}

\author{
Lin Zhu \\ ${ }^{1}$ Chongqing Normal University, Chongqing, 401331
}

Keywords: Music; "National Training Plan"; Course Music Teaching

\begin{abstract}
In order to improve the teaching knowledge and skills of teachers, the Ministry of Education and the Ministry of Finance have carried out the "National Teacher Training Program" (the "National Training Program"). The author of the unit from the beginning of 2010 to undertake the task of training in the training process, I found that its training objectives, curriculum system, teaching links with the music (normal) undergraduate professional reform direction of unity. For this task group will be two works carried out a comparative study.
\end{abstract}

\section{Introduction}

As the ordinary colleges and universities music education undergraduate professional training and basic education needs are not convergence, primary and secondary music education has become a "weak subject." The party and the state highly concerned about this issue, the Ministry of Education in December 2004 promulgated the "Musicology (teacher education) undergraduate professional curriculum reform guidance program", in 2006 and issued a "national college higher education (teacher education) undergraduate Professional compulsory course teaching guidelines ". The author's music school in September 2006 submits a research report and reform the implementation of the program. May 2007, it is approved by the Ministry of Education to become the Ministry of Education "Musicology (teacher education) undergraduate professional teaching reform pilot."

"Guo Pei plan" that the Ministry of Education, the Ministry of Finance in accordance with the party's 17th on "strengthening the construction of teachers, focusing on improving the quality of rural teachers," the requirements and "national long-term education reform and development plan" spirit, to further strengthen Teacher training, and comprehensively improve the quality of teachers, the joint "national teacher training program." Primary and secondary school teachers national training program, referred to as "national training plan", fully implemented in 2010. "China Peking Program" includes "primary and secondary school teachers' demonstration training project" and "central and western rural backbone teacher training project" two elements. It mainly includes the training of key teachers in primary and middle schools, the training of primary and secondary school teachers, the teacher training of class teachers, the training of teachers and students in the primary and middle schools, and the training of the backbone of the national primary and secondary school teachers and the demonstration and development and provision of a batch of high quality Training courses teaching resources for the "central and western rural backbone teacher training project" and primary and secondary school teachers professional development to provide strong support. The program takes five years as a cycle to complete the national backbone teacher training mission. Chongqing Normal University Music College is the Ministry of Education, "Guo Pei plan" model focused training institutions, from 2010 to undertake the national education project, five years to complete more than 20 national training model project training tasks, training from the national 3000 a number of music backbone teachers and music teaching and research staff, has accumulated a lot of training experience, the formation of a relatively fixed training team, training 
quality courses and training programs.

\section{Comparative Study of the Core Basis of the Undergraduate Course of Musicology and the Course of "Peking Education Plan"}

In the course of the implementation of the "China Peking Project", the members of the research group found that their teaching objectives were consistent with the teaching objectives of the undergraduate majors in musicology (normal), that is, the national training program was the same as that of music (normal) Reform and development.

Chongqing University Music (Normal) undergraduate professional training objectives is the students through the undergraduate stage of learning, growth to meet the requirements of the times and basic education reform needs, moral and physical development in all directions, master the basic theory of music, basic knowledge and basic skills with innovative spirit and practical ability of high-quality primary and secondary school music teachers. From the professional point of view, qualified music teachers need the following professional competence. First, master the basic theory of music, basic knowledge and basic skills necessary for school music education, including good music auditory and visual singing ability, basic music technology theoretical knowledge and certain music analysis ability, basic Chinese and foreign music historical knowledge, etc., with a considerable degree of vocal singing ability, piano playing and accompaniment, the initial master of a musical instrument playing methods, and can use this knowledge and skills to solve the basic problems of music teaching. Second, master the scientific education theory and methods, know the advanced educational ideas and ideas, understand the development trend of music education; correctly understand and grasp the nature of school music courses, values and goals, learn to use the law of music education in line with the teaching methods and scientific teaching evaluation methods, and the formation of the initial music teaching practice ability. Third, to be able to do the school music classroom teaching to guide the extracurricular art activities, to participate in the construction of campus cultural environment, through interdisciplinary penetration, access to a wide range of cultural literacy, and lay a solid foundation for lifelong learning.

The aim of the training is to "help primary and secondary school music teachers to update their educational concepts, expand their knowledge and teaching skills, enhance their practical experience, improve their research ability and form a cross-province learning community."

From the above comparison, the two have the following conclusions. First, the two talent training objectives are consistent, are to cultivate excellent primary and secondary school teachers. Second, cultivate the consistency of the content, update the concept of education, to enhance the music teachers' necessary professionalism and teaching skills, especially for the cultivation of practical experience, the two have coincidental commonality.

(1) Curriculum reform of undergraduate course in musicology (teacher) has promoted the reconstruction of curriculum system

In July 2013, according to "music education (teacher education) undergraduate curriculum reform guidance program" compulsory curriculum disciplines and kernel integration, the system "together" and other curriculum theory, reform of the music teacher education compulsory course.

The new curriculum system began in the fall of 2013, in the course of practice in accordance with the requirements of the school's academic office, the curriculum number, hours and credits were unified revision, complete and standardized into the office of the teaching management system. The results of the first phase of the pilot work through the Ministry of Education pilot mid-term acceptance. In 2016, "Ministry of Education Music (teacher education) undergraduate course teaching reform pilot exploration and practice" results won the Chongqing Normal University teaching achievement prize two.

The similarity between the curriculum system of the demonstration project of the national culture and the curriculum of the undergraduate course of musicology (normal)

The members of the research group collected and arranged more than 100 courses in the demonstration project of the National Peking University. Based on the training program of the 
undergraduates majoring in music science (normal) in Chongqing Normal University, the theme set up by the 2010-2015 demonstration project and the course reference, from the curriculum to open the goal, teaching content, internal links and other aspects of the comparative analysis, found that the two in the curriculum construction consistency. The specific content can refer to the following diagram.

According to the "Music Education (Teacher Education) undergraduate curriculum reform program" elective courses type requirements of the design reform of the music teacher education professional elective courses.

\begin{tabular}{|c|c|c|}
\hline \multicolumn{3}{|c|}{ New system of professional elective modules } \\
\hline Music theory & Music skills class & Music education class \\
\hline Introduction to Art & Ensemble and conductor & $\begin{array}{l}\text { A Brief History of } \\
\text { Chinese and Foreign } \\
\text { Music Education }\end{array}$ \\
\hline $\begin{array}{l}\text { Music } \\
\text { foundation }\end{array}$ & $\begin{array}{l}\text { The Application of Modern } \\
\text { Music Education Technology }\end{array}$ & $\begin{array}{l}\text { Comparison of } \text { Chinese } \\
\text { and Foreign } \\
\text { Education }\end{array}$ \\
\hline Music Review Basics & chamber music & $\begin{array}{ll}\text { Music } & \text { Education } \\
\text { Psychology } & \\
\end{array}$ \\
\hline $\begin{array}{lr}\text { An } & \text { Introduction to } \\
\text { Chinese } & \text { Traditional } \\
\text { Music } & \\
\end{array}$ & Music editor & $\begin{array}{lr}\text { A Brief Introduction to } \\
\text { Music } \\
\text { Philosophy }\end{array}$ \\
\hline harmony & stage performance & $\begin{array}{l}\text { Music education and } \\
\text { scientific research } \\
\text { methods }\end{array}$ \\
\hline Polyphony & Song writing and adaptation & Teacher speaking \\
\hline Song style & Small band player & Class management \\
\hline With the device & $\begin{array}{l}\text { Body training and dance director } \\
\text { foundation }\end{array}$ & $\begin{array}{l}\text { Psychological evaluation } \\
\text { of music education }\end{array}$ \\
\hline
\end{tabular}

\section{Conclusions}

From the above chart shows that we can see that music science (normal) undergraduate majors and primary and secondary school music teachers (national training program) key courses and connotation of a high degree of consistency, more than $90 \%$ of the courses can docking. The biggest feature is that the latter according to the needs of primary and secondary school music education teaching, undergraduate course teaching content of the multi-faceted development, refinement, enough to cause music (normal) undergraduate curriculum reform attaches great importance. Primary and secondary school music teacher "national training plan" course is more rich and specific, is the undergraduate curriculum development and supplement.

The reform of the curriculum system creatively uses the combination of "kernel integration", "categorization enrichment" and "system cohesion" to construct a new curriculum system. In the new curriculum system, to seize the harmony, music, polyphony, matching and other composition theory course "multi-part" kernel, integration for multi-part music analysis and writing a course; time and event as the main line, Music history and music appreciation; for classroom teaching for the purpose of the piano, vocal music, self-sing in the third grade fusion for the music teaching skills courses; "classification enrichment" school music education introduction and music courses and teaching theory compulsory courses the new curriculum system seamlessly "together" highlights the characteristics of music teacher education, and talent training objectives highly consistent. 


\section{Acknowledgements}

Chongqing Municipal Education Reform Topics. "Chongqing University Music (Normal) undergraduate professional and" National Peking University Program "resource sharing platform construction" No. 133068

\section{References}

[1] Sun Weixi, Song Bei. Junior high school music teacher professional development status and countermeasures research to Heilongjiang area as an example [J]. Art Education, 2016 (1): 85-86.

[2] Geng Fei, Ren Zhihong. Construction of the Curriculum System of Rural Music Teachers in Guo Pei Plan[J]. Industry and Technology Forum, 2016, 15 (2): 141-142.

[3] Ding Hui. "Guo Pei plan" rural primary and secondary school music teacher distance training course system construction [J]. Chinese music education, 2015 (7): 16-19.

[4] Cai Duoqi, Cai Mingfeng. "National Peking University Plan" in the construction of multiple music curriculum system [J]. Drama House, 2016 (8): 183-184. 